\title{
ENGLISH TEACHERS' DECISION IN UTILIZING TEXTBOOK IN THEIR CLASSROOM
}

\author{
Imelda Mallipa ${ }^{1}$ \\ UNIVERSITAS PAPUA \\ Riana Murianty ${ }^{2}$ \\ UNIVERSITAS PAPUA \\ i.mallipa@unipa.ac.id ${ }^{1}$ \\ Submit, 18-03-2019 Accepted, 04-06-2019 Publish, 04-06-2019
}

\begin{abstract}
This study was conducted at SMAN 1 Manokwari, West Papua. The data were collected through classroom observation and interview with two qualified English teachers in the school. The results showed that the English textbooks provided were the main learning source in teaching reading comprehension. The teachers contextually modified the sequence of the tasks and lessons from the textbooks before assigning them to the students in teaching speaking, listening and grammar. Some factors that were considered by the teachers in selecting materials were the availability of learning materials in school, students' needs, and students' level of English competence, school facilities and the national exam. The results of these study consider practical implications to give teachers, practioners, other reserachers and author of textbooks in developing teaching materials to be used in different context of classroom.
\end{abstract}

Keywords: the 2013 curriculum, decision making, textbook use

\section{INTRODUCTION}

The educational changing policies regarding the national curriculum demand teachers to reassess their teaching practices in classroom. The catalyst for these changes is the implementation of the 2013 curriculum (K-13) with new paradigm in teaching and learning all subjects in schools, including English subject. While the previous curriculum only focused on developing the standard of content to equip students with four English skills, the current curriculum emphasizes the standard of graduate competence to equip students with religious, social attitude, knowledge, and knowledge application. The acquired knowledge and skills from learning English subject are applied to overcome social problems in order to strengthen students' character with religious and socio-cultural values. Thus, to achieve the standards, all components such as core competences, basic competences, learning materials, learning scenario, time allocation, learning 
resources are provided by the curriculum planners (Basic Frameworks and Curriculum Structure (2013:13).

In the implementation of K-13, the ministry of Education and Culture of Indonesia produced textbooks as standard sources of information in teaching and learning in each level of school and as models of practice. The textbook provides the main basis for the curriculum. Research on textbooks had showed that the use of textbooks benefited teachers in their professional development (McDonald, 2016:481); Kong \& Shi, 2009:268). Thus, the textbooks can be used as a map and a sense of structure that gives coherence to individual lessons (Jack C. Richards, 2014:19). Furthermore, According to (Graves, 2000:230); (J.C Richards, 2001:23)\& (Basturkmen, 2010:60), the textbooks can benefited teachers in some ways for it is providing structure and a syllabus for a course. There is no doubt that the authors of the books have observed and investigated the requirement of curriculum in deciding the structure and syllabus of the books. The structure and syllabus of the book enable teachers to present and develop materials systematically. Thus, The implementation of textbook in classroom are needed to be investigated (Sulfasyah, Bahri, \& Saleh, 2018:495)

Many other sources are available on internet to be used nowadays as the impact of Information and Communication Technology (ICT) advancement. It might bring changes in the way teachers utilize textbooks in their classroom. There might be some factors that influence teachers to prefer use online materials. Thus, this present study investigated how English teachers used the provided textbook in their classroom and what factors influenced teachers' decisions regarding the use of the textbooks.

\section{LITERATURE REVIEW}

Textbooks are mostly used in English teaching and learning process. Textbook in this study refers to the printed materials that are provided by government to support the implementation of the 2013 curriculum. The English textbooks are designed to develop language competence of students. The textbooks are organized based on the Genre Based Approach. Genre is related to type of text. It is the classification of text based on three characteristics: the communication purpose, organization structure, and language features. The communication purpose or social function is the reasons to speak, write or create a text. Organization structure or generic structure is the way text is organized or arranged. Language features refer to grammar, vocabulary and connectors that are used in text.

The government provides book for teachers and books for students. The books for teachers are different from the books for students. The books for teachers give guidelines for teachers to design teaching activities in order to lead 
students participate actively in teaching and learning process. The books can help teachers to figure out the whole process of teaching English subject in each level. Teaching activities and steps are provided to enable teachers in giving clear instruction. The books for students provide teaching methodology, students' activities, and students' project. The topics and tasks are arranged in line with the objectives of teaching the subject in curriculum.

A textbook can have advantages in facilitating students to learn. It is supposedly to guarantee students of the same level but in different classes to receive similar content of learning, so that they can be tested in the same way. The roadmap that is offered by the author of a textbook is to ensure students to understand what is expected from them. The materials that are presented in textbooks have been tried and tested appropriately and are based on learning principles. Therefore, the use of textbook in teaching and learning process can help students to expose proper input of knowledge and skills.

Textbook provides a variety of learning resources. English Language Teaching (ELT) textbooks commonly provide various kinds of activities such as reading activities, listening activities by giving $\mathrm{CD}$, cassettes, writing activities, speaking activities, grammar activities and teaching guides. The various kind activities that are presented in textbook are meant to save the teacher's time; teachers can focus merely on the teaching rather than spending time on materials' production. Teaching guides that are provided by the author in textbook can serve as medium of initial teacher training especially for the novice teachers or inexperience teachers. They provide teachers with a base for assessing students' learning. Some textbooks include tests or evaluation tools. Some may also include supporting materials (teacher's guide, $\mathrm{CD}$, worksheets, and videos.)

One of the limitations of textbooks in terms of content is that a textbook may not contextually relevant to all the users (Graves 2000:60; Richard 2001:23 \& Basturkmen 2010:60). In this case, the diversity of students' needs and students' characteristics as well as the possibility of inauthentic language use can lead to the dissatisfaction of teachers and learners with the textbooks. In other words, the textbooks may not relevant for a group of a learners since learners' need are different from context to context. For instance, the content of reading can make reading activities are difficult for some students but easy for others. The students who are not familiar with the topic of reading text may find difficult to understand the reading text. The inauthentic language refers to the language that is not representative of real language. Reading text, dialogs and other aspects of content use language are written to incorporate teaching points. A textbooks may as well contain the idealized view of the world that inform learners how and what they should and understand about the theories and principles of the experts but do 
not encourage learners to think and solve the real issues that exist in their own context.

Teachers make various decisions regarding the textbook use since there is no perfect textbooks for a classroom need. Teachers need to decide whether they have to follow the sequence of tasks and lessons presented in the textbooks or they need to make some modification in some activities to meet their classroom needs (Kim, 2018:315). In introducing new knowledge and consolidating the learned knowledge, the teachers consider which instructions to be followed, which activities in their textbooks to be used and when they have to flexibility construct their own problems.

How teachers utilize textbooks can vary in the diverse environments. The teachers may essentially adopt their textbooks (Huang, Ozel, Li, \& Osborne, 2014:443), follow or modify the sequence of tasks and lessons presented in textbooks (Kim, 2018:315). (Miguel, 2015:309) in his research found that adaptation of activities was a very frequent process showing while (Qi, Zhang, \& Huang, 2018) found that the use of textbook reaches the level of elaborating and creating but most teachers still focused on elaborating level. The textbooks can be used as main sources or only a reference. Teachers may rely on textbooks or teachers may design their own course book to fulfill their classroom needs.

Adaptation of materials or activities in textbooks are frequently done by teachers in their teaching to fulfil their classroom needs (Miguel, 2015:309 \& Bosompem, 2014:34). Textbook adaptation can take form in modifying content, adding or deleting content, reorganizing content, addressing omissions, modifying tasks, and extending tasks. Teachers may modify content to suit target learners such their learners' age, gender, social class, occupation, religion or cultural background. When there is too much activities or tasks in book, teacher can delete or omit some of unnecessary content and if the activities or tasks are very few for the program, teacher may add some activities from other sources. When the way of the author organize the content of textbook does not suit the teachers' beliefs or does not fulfill the classroom need, the teachers can reorder the activities in the activity, in the unit, or in the syllabus level. Teachers may omit and add items such as vocabulary activities and grammar activities for certain reasons. Some activities in textbook can be changed or extended to accomplish the additional focus of teaching and learning.

Teachers' decisions regarding the use of the textbook are influenced by some factors such as the quality of the textbooks, teachers' pedagogic principles (Grammatosi \& Harwood, 2014:178; Pepin \& Haggarty, 2001:158), contextual factors or classroom context such as the needs, abilities, and interests of students (Grammatosi \& Harwood, 2014:178) (Pepin \& Haggarty, 2001:158), language policy, the social and personal dimensions of classroom teaching, teachers' 
knowledge, goals and beliefs (Silver \& Steele, 2005:107; Stahnke, Schueler, \& Roesken-Winter, 2016:70), teachers' belief about teaching, moral and cultural values (Lim \& Keuk, 2018:87); (Grant \& Wong, 2018:1); (Sidhu, Kaur, \& Fook, 2018:69); (Widodo, Perfecto, Van Canh, \& Buripakdi, 2018:34), (Van Canh, 2018:111), and different years of teaching (Qi et al., 2018:29).

\section{RESERCH METHODS}

This case study investigated teachers' decision regarding English textbooks use in their classroom. The samples of this study were two English teachers at SMAN 1 Manokwari. The two teachers hold teacher professional certificate, had a bachelor degree in English language Education, had more than five-year experiences in teaching English at SMAN 1 Manokwari and had joined teacher professional trainings related to the 2013 curriculum implementation. The data were collected by 270 minutes classroom observation, 40-45 minutes interviews for each teacher, and 10 WhatsApp chats with each teachers. In addition, pages of the textbook containing the lessons observed and the teachers' book guidance for the lesson observed were photocopied. The classroom observation was done to see the implementation of English textbook in classroom. To understand why teachers used or did not use their textbook, followed or did not follow the instructions in textbook, adopted or modified materials/activities provided in textbooks during teaching and learning process, the interview was conducted.

The data from classroom observation and interview were compared. The data were analyzed by hand. The hard-copy printouts of the transcript were read, summarized one by one, coded, categorized and identified links between of the codes in which similar codes dropped all together. To have general idea of the data, the literature on teachers' decision regarding English textbooks use was reviewed.

\section{FINDING}

Two teachers who were interviewed and observed their classes utilized textbook in their teaching and learning process. Table 1 summarizes the text book sections that teachers dealt with in their classroom. The sections in green were discussed in classes.

Table 1. Section and activities used

\begin{tabular}{lll}
\hline Sections in the Textbook & Teacher 1 & Teacher 2 \\
\hline Warmer & \\
\hline Vocabulary Builder \\
\hline \multicolumn{2}{l}{ Pronunciation Practice } \\
\hline
\end{tabular}




\begin{tabular}{l}
\hline Reading \\
\hline Text Structure \\
\hline Listening \\
\hline Vocabulary Exercises \\
\hline Grammar Review \\
\hline Writing \\
\hline Speaking \\
\hline
\end{tabular}

Table 1 illustrated that the teachers did not follow the sequence of tasks and lessons presented in the textbooks during their teaching process in classroom. However, the teachers utilized textbooks in class when the basic competences of learning activities were to understand and to analyze reading text. In this section, teachers used reading text and its reading comprehension test following provided in textbook. Extract 1 below revealed why teachers used textbook resources.

\section{Extract 1}

Dalam memilih bahan ajar, kita lebih patokan ke silabus. Kita melihat kompetensi dasar yang akan dicapai. Buku sangat menunjang terutama biasanya kalau Reading. Kita memakainya untuk Reading. Kalau mengajar text kan ada bacaannya. Disitu biasanya saya pakai bukunya.

kalau bahasa Inggris ada teksnya, susah kalau mau ditampilkan di projektor tidak efektif karena terlalu banyak tulisannya kalau mau fokus terus ke projektor.

kalau teks, karena kebanyaan disini kan buku yang banyak jadi pas sama siswa. Jadi kita pakai dari situ. Kan gak mungkin yang lain. Misalnya kelas isinya 40. Kan kita harus memperbanyak sampai 40 sementara kan yang available ya buku.

The teachers used textbook in their classroom based on basic competences stated in curriculum or syllabus. The basic competences were always the guidelines to choose the teaching or learning materials. Thus, the textbook was not the absolutely materials to be followed. On the other hand, the teachers admitted that when teaching reading text, the teachers usually decided to use materials in textbook directly. The textbook was the most available learning materials in school.

Teachers would extend task when they thought that students needed more exercises to practice in order to achieve the learning objectives that had been set for them. In observation session, teachers showed instances of adding task during 
the lessons. In teaching song, teacher 1 asked students to use their own favorite song lyric to understand and to analyze figurative languages, while teacher 2 asked students to discuss the moral message of the song that was provided by the teacher. Teachers also modified task when they thought that their students could understand the topic best by using different strategies. For instance, in teaching narrative text, teacher 1 grouped students based on their ethnic to compose a narrative in form of story derived from the legend of their ethnic groups and retold the story in front of the classroom. The narrative story had to be written and then retold using the text structure: orientation, complication, resolution, and moral value. Each part of the text should be presented by different member of group. Students were given time to do the task based on their ability to finish the task.

Another instance of extending task done by teachers was giving grammar task from grammar books. They stated that grammar was usually taught according to kinds of text presented, for instance, when the topic was about narrative text, the teacher needed to teach past tense for it was the language feature of the text.

Extract 2

biasanya menyatu dengan teks juga. Contohnya ketika kita mengajar narrative disitu ada past tense. Tapi kalau yang di kelas 10 ini, kebetulan kemarin saya mengajar kelas 10, itu ada grammarnya. Dia terpisah dari teks.

kalau grammar kita tidak bisah langsung bilang ini rumusnya. Mesti nyari prolognya apa. Baru masuk ke intinya. Tapi kan kelas yang kita ajar itu kan juga beda-beda kemamupuan siswa didalamnya. Ada yang kalau kelas bagus kita bisa langsung bilang materinya ini, rumusannya ini. Ada kelas lain yang harus kita jalan-jalan dulu baru masuk ke intinya.

The author of the textbook usually presented the grammar by showing the form of verbs with some examples that were used in text. In teachers' teaching experiences, students who had low ability in English did not get the point easily by simply learning the form of verbs. Therefore they thought they had to find other sources that provided more explanation, samples and exercises.

\section{Extract 3}

dalam ujian nasional, test grammar itu biasanya kayak gini, masuk kayak misalnya ada teks rumpang. Na ada yang kosong harus di isi, kemudian ada pilihannya disitu seperti go, went, jadi itu untuk kasih masuk itu harus bisa kira-kira, ini teksnya lampau jadi verbnya harus verb 2.

Even though English grammar was not directly tested in national test but tested by using the cloze procedure in which students were required to fill in the 
blanks of passage with using the right form of verb, students still needed the insight into the sentence structure and function.

When teachers used additional material from other sources, they put it in power point or asked students to bring article or materials found from other sources into classroom. Teachers provided some guidelines in choosing materials. Some students came with bringing the requirement material and some did not because they were still confused in choosing the appropriate source, and sometimes they had no internet facility to find online materials. Asking students to find additional material was done to encourage students to choose reading text in their own way. When the students found difficulty to do the task, the teachers gave more explanation by giving example using text provided in textbook.

\section{Extract 3}

sebelumnya kita juga sudah kasih petunjuk yang jelas supaya anak tidak salah bawa teksnya. Magsudnya, misalnya narrativepun saya tidak bilang narrative saja tapi khusunya misalnya legenda. Misalnya kalau descriptive nyari yang toursm object, itu toursm object dipekercil lagi yang ada di Manokwari.

misalnya sama-sama mengajar tentang descriptive teks, ada kelas yang kita bisa minta bawa sendiri tapi ada yang kita (guru) kasih (siapkan)

memudahkan siswa. Jadi sebelumnya kan kita sudah jelasin. Nanti mereka bisa menentukannya lagi sendiri. Tapi kalau mereka masih bingung ya kita pakai buku dulu.

Kadang bisa internet tapi nanti kadang ada yang akan bilang tidak ada pulsa

In teaching listening comprehension and skills, teachers used materials from internet. The teachers took dialogue that related to the topic and gave them to students. It was usually in video form taken from YouTube channels because students were more interested in watching video. After watching the conversation, the teacher gave some questions to test their listening comprehension. Teachers stated that it was necessary to encourage students to improve their listening skills by watching or listening to English conversation frequently because listening comprehension was usually tested in national test. The students would be tested how well they could use some language expressions that they had learned in real life communication. 


\section{Extract 4}

listeningnya itu di buku kadang gak ini listeningnya itu. Kadang saya biasanya saya cari sendiri. Misalnya ini, materi lagu, saya cari lagu sendiri. Sebenarnya ada di itu tapi tidak tahu lagunya sebelah mana. Di buku paket si ada teksnya. Ada lagunya. Tapi lagu tidak sesuai dengan lagu yang sekarang. Biasanya kan siswa senangnya lagu apa atau lagu yang lagi ngehit.

biasnya kita cari ini si, nyari dialog di you tobe. Nyari di iya, di siswa. Biasnya juga lewat video. Mereka kan biasa senang kalau video. Nanti dari situ kita sediakan beberapa pertanyaan yang dijawab saat mereka melihat videonya.

Teaching speaking and writing was more difficult for teachers. After students read a text or listened to some conversations, students were required to compose a text or create dialogue to be presented. Teachers had to provide some guidelines to do the task. Teachers stated that students with low level ability of English found difficulties to do the task. Most students in social classes usually were failed to meet the standard. Therefore, the teacher provided a text or dialogue for them instead. The students were only demanded to read, memorize and practice the task given. Teachers stated that sometimes the students still failed.

\section{Extract 5}

kalau speaking biasanya anak-anak disuru buat dialog dengan temannya tentang ungkapan yang mereka pelajari

jadi nanti mereka bikin speaking berdasarkan situasi yang diberikan. Apa yang kamu ucapkan jika ini ini in...sudah ada infromasinya to.

Tapi itu kalau di IPA bisa running well. Kalau di IPS kadang kita yang bikin dialog. Mereka tinggal hapalin saja.

Ada kelas yang kita tanya trus kita jawab sendiri. Dan ada kelas yang bisa jawab. Karena SDMnya berbeda

Kalau tidak bisa ya kita yang bikin speaking, jadi nanti mereka tinggal hapal dan latihan

Materials for teaching listening and speaking were designed based on teachers' creativity. Teachers thought that they tried to find way to correlate materials with their students' real life and grouped students to encourage them to learn the materials with their friends and learn to share. They believed that peer tutors was good for them in the process of understanding materials. Sometimes 
when it did not work, teachers took responsibility to explain. In some situations, the teacher remained the main sources of knowledge.

\section{Extract 6 \\ saya sering mengelompokkan mereka ketika belajar. Belajar berbagi. Bisa tutor sebaya. Tetapi saja pada akhirnya ya sumber utamanya tetap guru. Kalau teman tidak menyampaikan dengan baik ya tetap larinya ke guru.}

Teachers also incorporated character, moral and cultural values into ELT materials development. Teachers used the materials that contained culture elements in order to make students learn their own culture and other cultures. The students in a class came from different regions or ethnic groups with different cultures. Students were required to read, rewrote, and retold a story of their ethnic groups. By doing those activities, students were encouraged to feel proud of being one of an ethnic group. Students also got to know some stories from different regions by listening to stories that retold by other groups.

\section{Extract 6}

maksudnya saya disitu ya nilai-nilai karakternya yang saya ingin munculkan. Biar mereka juga tahu kalau mereka itu orang mana. Trus daerah mereka itu adanya cerita yang kayak gimana. Kalau gak, siapa lagi yang mau banggakan daerah kamu sendiri.

Trus teman yang lain juga bisa tahu kalau o dari daerah ini ada cerita tentang ini. Jadi mereka jadi tahu begitu

The decisions toward more constructivist teaching practice were made by teachers. Constructivist teaching practice included activating prior knowledge for example by asking students to write down a story in their own language, acquiring knowledge by giving some explanation about how to write a narrative story, understanding knowledge by asking some questions about generic structure of narrative story, using knowledge by writing the story in target language (English), and reflecting knowledge by retelling the story in front of the classroom. Teachers believed that engaging students in those activities could help students to understand the meaning of what they are saying, not only to memorize the story.

\section{Extract 7}

jadi ada ada yang presentasi orientation, conflict, resolution, moral vaue, cerita ini nilai-nilai moralnya apa. Dimulai dari menulis cerita dalam bahasa Indonesia ke bahasa Inggris. Na itu magsudnya supaya 
mereka tahu apa yang mereka hapal. Itu takutnya mereka Cuma hapal bahasa Inggrisnya tapi tidak tahu mereka bilang apa karena ada anak yang biasanya begitu, hapal mati saja. Saya ingin bahwa mereka ketika menyampaikan sesuatu itu mereka sadar dan tahu artinya.

However, the learning scenario could be changed any time the situations in classroom did not fit the scenario. Teachers stated that too often the practices in classroom were diffrerent from the steps in lesson plan.

\section{Extract 8}

kondisi dalam kelasnya berbeda-beda. jadi segala sesuatunya bisa beruba di kelas ya. sering itu yang saya sudah rencanakan, beda dengan yang di lapangan.

An example found in observation sessions was when the teacher decided not to ask students to present their story in front of class as stated in her lesson plan but presented in front of the teacher. The teacher gave confirmation in interview sessions why the teacher suddenly changed her plan.

\section{Extract 9 \\ sebenarnya idealnya menghadap ke teman-temannya, cuma kelas itu terus terang keadaannya sangat croweded jadi susah mereka memperhatikan belajarnya. Trus yang lainnya juga masih sibuk juga menghapalin mereka punya materi sendiri. Jadi idealnya menghadap ke temannya. Tapi mengingat situsainya Iya temannya sibuk dan stress dengan mereka punya tugas sendiri. Boro-boro dia mau perhatikan teman. Bahkan dia hapal dia punya saja belum tentu}

The teacher stated that it was not possible to force students giving attention to the presentation of their friends from other group because they still were busy to memorize their own story. This statement indicated the condition of students that were not ready to present at the time even though they had been given some times to do the task in groups at home were the main concern of teacher in making a decision.

Another consideration in the process of selecting teaching materials and strategies in teaching and learning process was national test. Teacher gave some tasks that were similar to the questions in national test. Teachers provided some guidelines to answer questions that might be the same form in national test even the text was different. 


\section{Extract 10}

saya sudah bilang juga kalau di ujian nasional bisa ceritanya tentang yang lain. Tapi yang penting kamu sudah bahwa nanya ini jawabannya kayak ini. Kan mereka sudah belajar tentang generic structure to. Jadi paling gak mereka sudah tahu cara menjawabnya walaupun teksnya beda-beda.

\section{DISCUSSION}

The present study was intended to explore teachers' decision in utilizing textbooks in their classroom. The case study of teachers' decision regarding the use of textbook was interpreted with the theoretical supports that were relevant to this study. Through combining interview data with classroom observations, it was found that teachers decided to use textbooks in their classroom to align their teaching materials with the basic competences stated in national curriculum, their students' needs and ability, their school facilities and the national examination.

Especially in reading skill, the use of reading material from the textbook as the main reading sources was because the texts were positively 2013 curriculumbased. In other words, the reading materials in the textbook were carefully arranged so the students were able to meet the objectives of 2013 curriculum which highlighted students' character development This was as (Huang et al., 2014:443) stated that the sample teachers in their research essentially adopted their textbook. In addition, teachers also assigned students to find written information of certain topics as homework and presented it in class. However, the homework was only considered as an additional credit for students, the main source for developing reading skill remained from the textbook as (Kim, 2018:315) suggested that teachers can follow or modify the sequence of tasks and lessons presented in textbooks. In this case, teachers used the reading text and tasks or exercises following in their teaching and process in classroom without made any change. In some cases teachers added exercises when teachers thought that the provided tasks in textbook did not give enough opportunities to exercise their knowledge and skills.

For speaking skill, the textbook tasks normally demanded students to make a dialogue according to certain given social functions. In this case, teachers were fully aware with the fact that their students' levels of English competence were still below the textbook's standard. Thus, to solve this problem, the teachers simply wrote the dialog for the students to practice in class. This practice fit the statement from Grammatosi \& Harwood (2014:178); Pepin \& Haggarty (2001:158) about teachers' considerations in preparing teaching material that included "contextual factors or classroom context such as the needs, abilities, and interests of students". 
The needs of students should be considered in choosing the suitable materials for them. Therefore, teachers thought that they should use materials and create meaningful activities based on students' interest and capacity or ability and used activities that could lead students to study. For instance, grouping students based on their ethnic to compose a narrative story derived from the legend of their ethnic groups using their own words then retold the story. Students gave enough time to do the task and did not force students to present when they were not ready. Another instance was when teachers decide whether to use English song in textbooks or found other songs. Teachers 1 used song that she thought the new song and related to students' life while teachers 2 used song that its lyric was easier to understand by students and had positive messages.

The availability of learning facilities also played an important role. In this case, authentic learning source such as English books in the school was nonexistent. Therefore, if the teachers were demanded to develop the material from the textbook, it would be burdensome for them; they needed to provide extra time and money in regular basis. Therefore, the teachers preferred to religiously use the textbook instead of developing the material by themselves. However, extra homework was normally provided by the teacher when they found that the textbook was too difficult for their students' level of English mastery, especially for grammar section. This had been done to help students with low level of English mastery to cope with grammar learning.

When teachers decided to give homework outside the textbook, they would definitely insert their belief about teaching, moral and cultural values into it. This could be seen when they asked the students to make a narrative composition; the story had to be a story of their origin. Manokwari was considered as a melting pot where people from all over Indonesia came and started a living. Some families even had been resided for more than three generations. Therefore, teachers' approach to involve students' origin in their learning was very interesting; students were able to learn new knowledge about each other's precious cultures aside from the local culture of Manokwari which they had already known. This findings were in line with the findings from Lim \&Keuk, (2018:87); Grant \& Wong, (2018:1); Sidhu, Kaur, \&Fook, (2018:69); and Widodo, Perfecto, Van Canh \& Buripakdi, (2018:67).

Another reason is the way students tested in national test. Students' examination scores were seen as one of indicators to know the successful of teaching and learning process in English classroom. Teachers took into account the possibility of items in national test and taught according to it.

Overall, the findings of this study are in support the study of Qi, Zhang, \& Huang (2018:29) who showed the use of textbook reached the level of elaborating and creating but most teachers still focused on elaborating level. 


\section{CONCLUSION}

The decision making regarding the text book use in this study was not seen as a complex process but it was not simple task for teachers when came to teaching practice in classroom especially in presenting teaching materials to students. The study that was began with classroom observation to discover how the textbook implemented in classroom showed that the textbook was utilized in teaching and learning process by adopting the provided reading text and task following but in some parts, the tasks were extended by adding tasks from other resources. The reason behind every teachers' decision was investigated by asking teachers in interview sessions. It was found that there were some factors considered by teachers in using materials in their classroom, the factors were the availability of learning materials in school, students' needs, and students' level of English competence, school facilities and the national exam. There were no specific steps followed by teachers in the process of selecting materials to be presented in classroom. The availability of alternative resources on internet did not give any effect in the way teachers utilize textbooks in their classroom for the lack of internet facility in schools. The printed material provided by government played important role in helping teachers to deliver materials more effectively and in facilitating their students to study in order to achieve the standards of learning competences stated in national curriculum. Therefore, textbooks that are used as standard source of learning to achieve the goals of national curriculum should contain various activities and choices for teachers especially the sources of speaking and listening materials. It is recommended to the next researcher to develop valid instruments in order to discover teachers understanding of the 2013 curriculum principles in teaching English and to train teachers in developing materials that meet the classroom context.

\section{REFERENCES}

Basturkmen, H. (2010). Developing Courses in English for Specific Purposes. New York: Paglave Macmillan.

Grammatosi, F., \& Harwood, N. (2014). An Experienced Teacher's Use of the Textbook on an Academic English Course: A Case Study. In N. Harwood (Ed.), English Language Teaching Textbooks (pp. 178-204). https://doi.org/10.1057/9781137276285_6

Grant, R., \& Wong, S. (2018). Addressing Cultural Bias in ELT Materials. In J. I. Liontas, T. International Association, \& M. DelliCarpini (Eds.), The TESOL Encyclopedia of English Language Teaching (pp. 1-8). https://doi.org/10.1002/9781118784235.eelt0315

Graves, K. (2000). Designing Language Courses: A Guide for Teachers. Boston: MA: Heinle \& Heinle.

Huang, R., Ozel, Z. E. Y., Li, Y., \& Osborne, R. V. (2014). Does Classroom Instruction Stick to Textbooks? A Case Study of Fraction Division. In Y. 
Li \& G. Lappan (Eds.), Mathematics Curriculum in School Education (pp. 443-464). https://doi.org/10.1007/978-94-007-7560-2_21

Kim, O.-K. (2018). Teacher Decisions on Lesson Sequence and Their Impact on Opportunities for Students to Learn. In L. Fan, L. Trouche, C. Qi, S. Rezat, \& J. Visnovska (Eds.), Research on Mathematics Textbooks and Teachers' Resources (pp. 315-339). https://doi.org/10.1007/978-3-31973253-4_15

Kong, F., \& Shi, N. (2009). Process analysis and level measurement of textbooks use by teachers. Frontiers of Education in China, 4(2), 268-285. https://doi.org/10.1007/s11516-009-0014-1

Lim, S., \& Keuk, C. N. (2018). A Sociocultural Analysis of Cambodian Teachers' Cognitions about Cultural Contents in an 'Internationally Imported' Textbook in a Tertiary English Learning Context. In H. P. Widodo, M. R. Perfecto, L. Van Canh, \& A. Buripakdi (Eds.), Situating Moral and Cultural Values in ELT Materials (Vol. 9, pp. 87-110). https://doi.org/10.1007/978-3-319-63677-1_6

McDonald, C. V. (2016). Evaluating Junior Secondary Science Textbook Usage in Australian Schools. Research in Science Education, 46(4), 481-509. https://doi.org/10.1007/s11165-015-9468-8

Miguel, N. M. (2015). Textbook Consumption in the Classroom: Analyzing a Classroom Corpus. Procedia - Social and Behavioral Sciences, 198, 309319. https://doi.org/10.1016/j.sbspro.2015.07.449

Pepin, B., \& Haggarty, L. (2001). Mathematics textbooks and their use in English, French and German classrooms:: a way to understand teaching and learning cultures. Zentralblatt Für Didaktik Der Mathematik, 33(5), 158175. https://doi.org/10.1007/BF02656616

Qi, C., Zhang, X., \& Huang, D. (2018). Textbook Use by Teachers in Junior High School in Relation to Their Role. In L. Fan, L. Trouche, C. Qi, S. Rezat, \& J. Visnovska (Eds.), Research on Mathematics Textbooks and Teachers' Resources (pp. 29-51). https://doi.org/10.1007/978-3-319-73253-4_2

Richards, Jack C. (2014). The ELT Textbook. In S. Garton \& K. Graves (Eds.), International Perspectives on Materials in ELT (pp. 19-36). https://doi.org/10.1057/9781137023315_2

Richards, J.C. (2001). Curriculum Development in Language Teaching. Cambridge: University Press.

Sidhu, G. K., Kaur, S., \& Fook, C. Y. (2018). Analysing the Integration of Moral and Cultural Values through ELT Reading Materials in Malaysian ESL Classrooms. In H. P. Widodo, M. R. Perfecto, L. Van Canh, \& A. Buripakdi (Eds.), Situating Moral and Cultural Values in ELT Materials (Vol. 9, pp. 69-85). https://doi.org/10.1007/978-3-319-63677-1_5

Silver, R. E., \& Steele, R. S. (2005). Priorities in english language education Policy and classroom implementation. Language Policy, 4(1), 107-128. https://doi.org/10.1007/s10993-004-6567-1

Sulfasyah, S., Bahri, A., \& Saleh, S. F. (2018). WRITING LESSONS IN GRADE 1 INDONESIAN THEMATIC TEXTBOOKS: A CONTENT 
ANALYSIS. Indonesian Journal of Applied Linguistics, 7(3), 495. https://doi.org/10.17509/ijal.v7i3.9789

Van Canh, L. (2018). A Critical Analysis of Moral Values in Vietnam-Produced EFL Textbooks for Upper Secondary Schools. In H. P. Widodo, M. R. Perfecto, L. Van Canh, \& A. Buripakdi (Eds.), Situating Moral and Cultural Values in ELT Materials (Vol. 9, pp. 111-129). https://doi.org/10.1007/978-3-319-63677-1_7

Widodo, H. P., Perfecto, M. R., Van Canh, L., \& Buripakdi, A. (Eds.). (2018). Situating Moral and Cultural Values in ELT Materials. https://doi.org/10.1007/978-3-319-63677-1 